\title{
COAST: A Comprehensive Older-Adult Screening Tool ${ }^{1}$
}

\author{
Karima Alabasi, Nancy J. Gal, and Wendy J. Dahl²
}

Malnutrition results from the lack of adequate nutrition to maintain good health (Moreira et al. 2016). Of particular concern in older adults is malnutrition resulting from inadequate protein and energy (calories), which leads to muscle loss (Crichton et al. 2019). Nutrition risk screening is a first step to quickly identify individuals who might be malnourished or at risk of malnutrition. A malnutrition screening tool should be easy to use, quick to administer, and valid-that is, able to correctly identify those at risk of malnutrition. The Comprehensive Older Adult Screening Tool (COAST) is a valid and practical tool to determine if community-dwelling older adults are at risk for malnutrition (Alabasi et al. 2018). For malnutrition screening with COAST, older adults are considered to be those individuals over the age of 60 years.

There is a high prevalence of malnutrition among community-dwelling older adults, particularly in rural communities (Crichton et al. 2019). Malnutrition is a significant health concern because it is associated with frailty (Lorenzo-Lopez et al. 2017), reduced quality of life (Rasheed and Woods 2013), and mortality (Shakersain et al. 2016). Older adults receiving congregate and homedelivered meal services are at higher risk of malnutrition than the US older-adult population as a whole due to their lower health, functional, and financial status (Lloyd and Wellman 2015).

Unintended weight loss results from not consuming enough calories and may lead to malnutrition. In addition, many older adults may not consume adequate protein, putting them at risk for malnutrition (ter Borg et al. 2015). A high level of evidence supports poor appetite, hospitalization, eating dependency, poor self-perceived health, and poor physical functioning as determinants of malnutrition (O'Keeffe et al. 2018). A recent study confirmed that risk of malnutrition is increased in older adults with poor appetite and eating difficulties, as well as in those with respiratory and gastrointestinal diseases (Kiesswetter et al. 2020). The COAST was designed to target these risk factors with questions about unintended weight loss, appetite, changes in the kind/amount of food eaten due to illness and health conditions, and intake of protein foods. Although diet quality is not associated with protein-energy malnutrition (Hengeveld et al. 2018), the question "How healthy is your overall diet?" was added as a proxy for diet quality, specifically intake of fruits and vegetables, because this may be a strong indicator of vitamin and mineral intake (Loftfield et al. 2015).

There are many malnutrition screening tools, and some are intended for community-dwelling older adults (Isautier et al. 2019). One such tool, the Malnutrition Screening Tool (MST), has recently been recommended for malnutrition screening in all adults regardless of age and in all settings (Skipper et al. 2020). However, its low specificity in older adults in community settings is a concern (Dwyer et al. 2019). In addition, it relies on an estimate of weight loss that may not be known and offers logistical challenges for measurement in a community setting. In addition, the Mini

1. This document is FSHN20-37, one of a series of the Food Science and Human Nutrition Department, UF/IFAS Extension. Original publication date July 2020. Visit the EDIS website at https://edis.ifas.ufl.edu for the currently supported version of this publication.

2. Karima Alabasi, former doctoral student, Food Science and Human Nutrition Department, UF/IFAS Extension; Nancy J. Gal, Extension agent IV, UF/IFAS Extension Marion County; and Wendy J. Dahl, associate professor, Food Science and Human Nutrition Department, UF/IFAS Extension, Gainesville, FL 32611.

The Institute of Food and Agricultural Sciences (IFAS) is an Equal Opportunity Institution authorized to provide research, educational information and other services

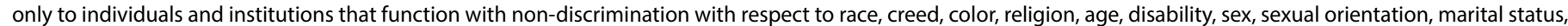

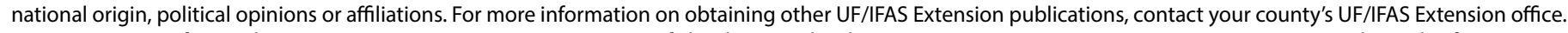
U.S. Department of Agriculture, UF/IFAS Extension Service, University of Florida, IFAS, Florida A \& M University Cooperative Extension Program, and Boards of County Commissioners Cooperating. Nick T. Place, dean for UF/IFAS Extension. 
Nutrition Assessment Short-Form (MNA-SF) is commonly used to screen for malnutrition in clinical environments but requires measuring height and weight, or alternatively calf circumference, which may be time consuming and challenging to conduct in the community.

The COAST was designed to be brief. It has only five questions and can be administrated by interview or self-screening. The COAST was developed specifically for older adults of lower socioeconomic status at high risk of malnutrition. This is in contrast to other screening tools that target the general older adult population (Morrison, Laur, and Keller 2019).

Identifying older adults who are at risk for malnutrition is needed to ensure they receive appropriate referrals for food and nutrition services. Because the COAST was developed for screening at congregate meal sites and other low socioeconomic groups of older adults, the tool may be ideally suited for longer-term outcome evaluation of Extension nutrition education programs targeted at these populations. 


\section{COAST (Interview)}

First name: Last name:

Date

1. Have you lost weight recently without trying? (Ferguson et al. 1999)

$0=$ Yes

$1=$ No

2. Have you been eating less food because of a decreased appetite? (Ferguson et al. 1999)

$0=$ Yes

$1=\mathrm{No}$

3. Do you have an illness or condition that has made you change the kind and/or amount of food you eat? (Nutrition Screening Initiative 1994)

$0=$ Yes

$1=$ No

4. In general, how healthy is your overall diet? (Loftfield et al. 2015)

$0=$ Poor

$1=$ Good

$2=$ Very good

5. Do you consume...

- Dairy products (milk, cheese, yogurt) or soy milk at least once a day? Yes No

- Meat, poultry (e.g., chicken), fish/seafood, or eggs every day? Yes No

- Legumes (e.g., beans), soy products, nuts, or seeds at least twice a week? (Vellas et al. 1999) Yes No

$0=$ If 0 yes response

$1=$ If one yes response

$2=$ If two yes responses

$3=$ If three yes responses

Screening score (subtotal max 8 points)

7-8 points: $\square$ At low risk of malnutrition

5-6 points: $\square$ At moderate risk of malnutrition

0-4 points: $\square$ At high risk of malnutrition 


\section{Coast}

1. Have you lost weight recently without trying? (Ferguson et al. 1999)

Yes

No

2. Have you been eating less food because of a decreased appetite? (Ferguson et al. 1999)

Yes

No

3. Do you have an illness or condition that has made you change the kind and/or amount of food you eat? (Nutrition Screening Initiative 1994)

Yes

No

4. In general, how healthy is your overall diet? (Loftfield et al. 2015)

Poor

Good

Very good

5. Do you consume...

- Dairy products (milk, cheese, yogurt) or soy milk at least once a day?

Yes

No

- Meat, poultry (e.g., chicken), fish/seafood, or eggs every day?

Yes

No

- Legumes (e.g., beans), soy products, nuts, or seeds at least twice a week? (Vellas et al. 1999)

Yes

No 


\section{References}

Alabasi, K., N. Gal, A. Fatani, L. Mead, and W. Dahl. 2018. "Development and Validation of a Comprehensive Older Adult Screening Tool (COAST): A Practical Tool for Identifying Malnutrition Risk." Journal of the Academy of Nutrition and Dietetics 118 (9): A27. https://doi. org/10.1016/j.jand.2018.06.281.

Crichton, M., D. Craven, H. Mackay, W. Marx, M. de van der Schueren, and S. Marshall. 2019. "A Systematic Review, Meta-analysis and Meta-regression of the Prevalence of Protein-Energy Malnutrition: Associations with Geographical Region and Sex." Age and Ageing 48 (1): 38-48. https:// doi.org/10.1093/ageing/afy144.

Dwyer, J. T., J. J. Gahche, M. Weiler, and M. B. Arensberg. 2019. "Screening Community-Living Older Adults for Protein Energy Malnutrition and Frailty: Update and Next Steps." Journal of Community Health 45: 640-660. https:// doi.org/10.1007/s10900-019-00739-1.

Ferguson, M., S. Capra, J. Bauer, and M. Banks. 1999. “Development of a Valid and Reliable Malnutrition Screening Tool for Adult Acute Hospital Patients." Nutrition 15 (6): 458-64. https://doi.org/10.1016/s0899-9007(99)00084-2.

Hengeveld, L. M., H. A. H. Wijnhoven, M. R. Olthof, I. A. Brouwer, T. B. Harris, S. B. Kritchevsky, A. B. Newman, and M. Visser. 2018. "Prospective Associations of Poor Diet Quality with Long-Term Incidence of Protein-Energy Malnutrition in Community-Dwelling Older Adults: The Health, Aging, and Body Composition (Health ABC) Study." American Journal of Clinical Nutrition 107 (2): 155-164. https://doi.org/10.1093/ajcn/nqx020.

Isautier, J. M. J., M. Bosnic, S. S. Y. Yeung, M. C. Trappenburg, C. G. M. Meskers, A. C. Whittaker, and A. B. Maier. 2019. "Validity of Nutritional Screening Tools for Community-Dwelling Older Adults: A Systematic Review and Meta-analysis." Journal of the American Medical Directors Association 20 (10): 1351.e13-1351.e25. https:// doi.org/10.1016/j.jamda.2019.06.024.

Kiesswetter, E., M. G. Colombo, C. Meisinger, A. Peters, B. Thorand, R. Holle, K. H. Ladwig, H. Schulz, E. Grill, R. Diekmann, E. Schrader, P. Stehle, C. C. Sieber, and D. Volkert. 2020. "Malnutrition and Related Risk Factors in Older Adults from Different Health-Care Settings: An Enable Study." Public Health Nutr. 23 (3): 446-456. https:// doi.org/10.1017/s1368980019002271.
Lloyd, J. L., and N. S. Wellman. 2015. "Older Americans Act Nutrition Programs: A Community-Based Nutrition Program Helping Older Adults Remain at Home." Journal of Nutrition in Gerontology and Geriatrics 34 (2): 90-109. https://doi.org/10.1080/21551197.2015.1031592.

Loftfield, E., S. Yi, S. Immerwahr, and D. Eisenhower. 2015. "Construct Validity of a Single-Item, Self-Rated Question of Diet Quality." Journal of Nutrition Education and Behavior 47 (2): 181-7. https://doi.org/10.1016/j.jneb.2014.09.003.

Lorenzo-Lopez, L., A. Maseda, C. de Labra, L. RegueiroFolgueira, J. L. Rodriguez-Villamil, and J. C. Millan-Calenti. 2017. "Nutritional Determinants of Frailty in Older Adults: A Systematic Review." BMC Geriatrics 17 (1): 108. https:// doi.org/10.1186/s12877-017-0496-2.

Moreira, N. C., S. Krausch-Hofmann, C. Matthys, C. Vereecken, E. Vanhauwaert, A. Declercq, G. E. Bekkering, and J. Duyck. 2016. "Risk Factors for Malnutrition in Older Adults: A Systematic Review of the Literature Based on Longitudinal Data." Adv. Nutr. 7 (3): 507-22. https://doi. org/10.3945/an.115.011254.

Morrison, J. M., C. V. Laur, and H. H. Keller. 2019. "SCREEN III: Working towards a Condensed Screening Tool to Detect Nutrition Risk in Community-Dwelling Older Adults Using CLSA Data." European Journal of Clinical Nutrition 73 (9): 1260-1269. https://doi.org/10.1038/ s41430-019-0411-3.

Nutrition Screening Initiative. 1994. "The Determine Your Nutritional Health Checklist.” Wash. Nurse 24 (2): 14-15.

O’Keeffe, M., M. Kelly, E. O’Herlihy, P. W. O’Toole, P. M. Kearney, S. Timmons, E. O'Shea, C. Stanton, M. Hickson, Y. Rolland, C. Sulmont Rosse, S. Issanchou, I. Maitre, M. Stelmach-Mardas, G. Nagel, M. Flechtner-Mors, M. Wolters, A. Hebestreit, L. C. P. G. M. De Groot, O. van de Rest, R. Teh, M. A. Peyron, D. Dardevet, I. Papet, K. Schindler, M. Streicher, G. Torbahn, E. Kiesswetter, M. Visser, D. Volkert, and E. M. O’Connor. 2018. "Potentially Modifiable Determinants of Malnutrition in Older Adults: A Systematic Review." Clinical Nutrition 38 (6): 2477-2498. https:// doi.org/10.1016/j.clnu.2018.12.007.

Rasheed, S., and R. T. Woods. 2013. "Malnutrition and Quality of Life in Older People: A Systematic Review and Meta-analysis." Ageing Research Reviews 12 (2): 561-6. https://doi.org/10.1016/j.arr.2012.11.003. 
Shakersain, B., G. Santoni, G. Faxen-Irving, D. Rizzuto, L. Fratiglioni, and W. Xu. 2016. "Nutritional Status and Survival among Old Adults: An 11-Year Population-Based Longitudinal Study." European Journal of Clinical Nutrition 70 (3): 320.

Skipper, A., A. Coltman, J. Tomesko, P. Charney, J. Porcari, T. A. Piemonte, D. Handu, and F. W. Cheng. 2020. "Position of the Academy of Nutrition and Dietetics: Malnutrition (Undernutrition) Screening Tools for All Adults." Journal of the Academy of Nutrition and Dietetics 120 (4): 709-713. https://doi.org/10.1016/j.jand.2019.09.011.

ter Borg, S., S. Verlaan, D. M. Mijnarends, J. M. G. A. Schols, L. C. P. G. M. De Groot, and Y. C. Luiking. 2015. "Macronutrient Intake and Inadequacies of CommunityDwelling Older Adults, a Systematic Review." Annals of Nutrition and Metabolism 66 (4): 242-255. https://doi. org/10.1159/000435862.

Vellas, B., Y. Guigoz, P. J. Garry, F. Nourhashemi, D. Bennahum, S. Lauque, and J. L. Albarede. 1999. “The Mini Nutritional Assessment (MNA) and Its Use in Grading the Nutritional State of Elderly Patients." Nutrition 15 (2): 116-22. https://doi.org/10.1016/s0899-9007(98)00171-3. 